\title{
Afrikaansontmagtiging
}

\section{Disempowerment of Afrikaans}

\author{
Willem J Botha \\ Departement Afrikaans \\ Universiteit van Johannesburg \\ Suid-Afrika \\ E-pos:wjb03@telkomsa.net
}

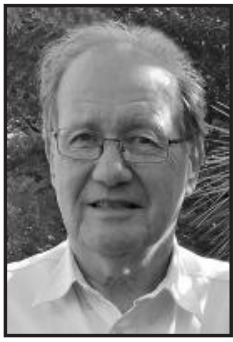

Willem Botha

Willem Botha is emeritus professor aan die departement Afrikaans aan die Universiteit van Johannesburg (UJ). Hy was vir nege jaar voorsitter van hierdie departement aan die destydse Randse Afrikaanse Universiteit (RAU), en vir ses jaar redakteur van die meningsblad "Aambeeld" aan die RAU; en gedurende 2001 was hy gasprofessor aan die Universiteit Leiden, Nederland. Sy fokusgebiede binne die taalkunde is semantiek en sintaksis. Sy semantieknavorsing bedryf hy veral vanuit die raamwerk van die kognitiewe linguistiek. Hy was sedert die stigting van die International Cognitive Linguistics Association (ICLA) 'n lid daarvan, het baie jare lank aktief aan die bedrywighede van die vereniging deelgeneem en het by talle kongresse referate gelewer. Van sy navorsing is ook onder die vaandel van die betrokke vereniging internasionaal gepubliseer.
Willem Botha is professor emeritus in the department Afrikaans at the University of Johannesburg (UJ). Formerly, he was chair of the department at the then Rand Afrikaans University (RAU) for nine years, and editor of the opinion journal, "Aambeeld", for six years; in addition, in 2001 he was guest professor at the University of Leiden in the Netherlands. He focusses, in his linguistic activities on semantics and syntax. His research in semantics is done mainly within the framework of cognitive linguistics. He has been a member of the International Cognitive Linguistics Association (ICLA) since its establishment, has for many years actively taken part in its activities and has read papers at numerous conferences. Many of his articles have been published internationally under the auspices of this association.

\begin{abstract}
Disempowerment of Afrikaans

Afrikaans, like any other language, is not merely a medium of communication. Should one hold such an opinion, one tends to consider only the symbolic nature of the specific language. That is exactly the view taken by those who wish to reduce the formal and official status of Afrikaans. It enables them to use metaphorical mappings to link Afrikaans with the stigmatised concept APARTHEID.
\end{abstract}

1 Van die gedagtes in hierdie artikel uitgespreek, is ook vervat in die volgende artikel: Botha, Willem J. 2020. Die daad onthul (im)moraliteit. Tydskrif vir Geesteswetenskappe, 60(2):366-379.

\begin{tabular}{l} 
Datums: \\
Ontvang: 2020-04-20 Goedgekeur: 2020-08-24 $\quad$ Gepubliseer: Desember 2020 \\
\hline
\end{tabular}


The conceptual metaphor AFRIKAANS IS APARTHEID is scrutinised in order to exemplify language metaphors such as "Afrikaans is the language of apartheid", "Afrikaans is a language of exclusion" and other pejorative labels.

To come to a conclusion with regard to the nature of the different language metaphors that are used to the disadvantage of Afrikaans, different meanings of the word Afrikaans are looked into. The view is taken that the central meaning of the word Afrikaans is disregarded in favour of a symbolic meaning to enable various emotive experiences of apartheid to be linked to the concept AFRIKAANS. Such a metaphorical strategy contributes to the disempowerment of Afrikaans.

When one considers the morality of such actions to disempower Afrikaans, it is obvious that the question of truth comes to the fore. Different dimensions of truth are outlined in order to establish a background knowledge against which morality should be considered if one wishes to understand the actions targeting the formal and official status of Afrikaans.

MORALITY is a very complex concept. To analyse its role in the disempowerment of Afrikaans, we have to view the phenomenon of morality within a specific theoretical framework. It is done against the background of the three broad discoveries made within cognitive linguistics. Lakoff and Johnson (1999:3) formulate these as follows: "The mind is inherently embodied. Thought is mostly unconscious. Abstract concepts are largely metaphorical."

According to this view, morality is to be understood as the manifestation of the MORAL ACCOUNTING conceptual metaphor. Considering this metaphor, one has to realise that the general metaphor of MORAL ACCOUNTING consists of a small number of basic moral schemes, namely "reciprocation", "retribution", "revenge", "restitution", “altruism”, "turning the other cheek", "karma" and "fairness",.

The most relevant moral scheme that applies regarding the disempowerment of Afrikaans, is the fairness scheme. But this scheme as such also has its own complexities, entailing amongst others the following models: equality of distribution, equality of opportunity, procedural distribution, rights-based fairness, need-based fairness, scalar distribution, contractual distribution, equal distribution of responsibility, scalar distribution of responsibility and equal distribution of power. Lakoff and Johnson (1999:296/297) rightly remark: "Many of our moral disagreements arise from conflicts between two or more of these conceptions of fairness" ... and "there is typically no overarching neutral conception of fairness that can resolve the conflict of values".

The remainder ot this article investigates the way in which the demise of Afrikaans in the formal and official contexts can be attributed to the fact that fairness is mostly determined by interpretations of the concept TRANSFORMATION.

KEYWORDS: $\quad$ Afrikaans, symbol, concept, metaphor, emotion, morality, disempowerment, transformation, truth, fairness

TREFWOORDE: Afrikaans, simbool, konsep, metafoor, emosie, moraliteit, ontmagtiging, transformasie, waarheid, billikheid

\section{OPSOMMING}

Afrikaans, soos enige ander taal, is nie slegs 'n kommunikasiemedium nie. Indien dit die vertrekpunt sou wees, vereenvoudig dit diegene se pogings om die waarde van Afrikaans tot blote kommunikasiemiddel te reduseer. Die simboolgeaardheid van taal word gevolglik in die kollig geplaas om 'n strategie aan te dui wat ideologiese manipulasie in die hand werk.

Op grond van die feit dat pejoratiewe taaluitdrukkings in die verlede (en steeds) Afrikaans gemetaforiseer het as 'n lewende entiteit, kon die begripsmetafoor AFRIKAANS IS APARTHEID as 
uitvloeisel van die betekenisse van genoemde metafore vir bepaalde konseptualiseerders dien. Dit het meegebring dat ' $n$ bepaalde negatiewe affektiewe betekenisdimensie aan die taal Afrikaans toegevoeg is.

Afrikaans is gevolglik bejeën teen die agtergrond van 'n moraliteitskragveld op grond waarvan Afrikaans se status om bepaalde ideologiese redes afgeskaal is in teenstelling met die status wat dit voorheen gehad het. Afrikaans word gesien as apartheidstaal, 'n taal wat transformasie blokkeer en ' $n$ taal wat mense binne formele en amptelike omgewings uitsluit.

Verder word in die hierdie artikel die konseptuele metafoor AFRIKAANS IS APARTHEID ontleed, en word daar aangedui hoedat ' $n$ oneweredige konseptuele invoer uit bepaalde denkruimtes Afrikaans noodwendig in 'n ongunstige posisie plaas. Daar word ook gewag gemaak van wat "conceptual framing" genoem word, ook beskryf as "conceptual engineering" of konseptuele inperking, en hoedat Afrikaans se status deur die genoemde strategieë benadeel word.

Die konseptuele struktuur van die begrip TRANSFORMASIE word onder die loep geneem om aan te toon hoedat die woord transformasie gebruik word om Afrikaans moreel in onguns te bring omdat Afrikaans sogenaamd transformasie blokkeer.

'n Uiteensetting word gegee van die kompleksiteit van die begrip MORALITEIT. Teen die agtergrond van die verskillende moraliteitskemas word die billikheidskema met betrekkking tot Afrikaans ontleed. Besluitnemers oor die status van Afrikaans in die verlede, tans en in die toekoms word onderwerp aan enkele indringende vrae waaroor uitsluitsel gekry moes word - of in die toekoms gekry sal moet word.

\section{INLEIDING}

"Ons is gebind / aan die lot in die stink kloaak van hierdie Ryk, / en die vuil van hierdie tyd spoel oor ons almal." (Germanicus 1961:74).

Dit is woorde deur keiser Tiberius (in die drama Germanicus, deur NP van Wyk Louw) gebruik, verwysend na die immorele tyd en omstandighede waarin hy vereensaamde slagoffer word op grond van sy eie immorele dade. Binne baie kontekste mag hierdie woorde waar wees ten opsigte van bepaalde tydruimtelike omstandighede. In die teenswoordige Suid-Afrika word baie ooreenkomstige verwyte gehoor ten opsigte van die toedrag van sake tans - maar soortgelyk ook verwyte met betrekking tot die vorige Suid-Afrikaanse bedeling. Op grond van bepaalde ideologiese beskouings was en is die lot van Afrikaans heg verweef met die morele vergrype van die verlede (Afrikaans as sogenaamde apartheidstaal) en die hede (Afrikaans as sogenaamde obstruksie vir transformasie). Verder aan word hierdie beskouings en uitsprake in meer besonderhede bespreek.

Die Suid-Afrikaanse Grondwet (1996) is geskryf om onder andere immoraliteite van die verlede te besweer deur bepaalde regstellende meganismes daarin te inkorporeer. Afrikaans het nie onaangeraak gebly nie!

Soos in enige gemeenskap was daar ook geïnstitusionaliseerde en nie-geïnstitusionaliseerde simbole wat ' $n$ bepaalde bindingskrag ten opsigte van die gemeenskap en sekere sektore van die gemeenskap gehad het. Die belangrikste geïnstitusionaliseerde simbole is vervang, ander het gebly - en nog ander het gebly en is gestigmatiseer. Afrikaner ${ }^{2}$ en Afrikaans is onder andere

2 Vergelyk Botha (2002) vir 'n bespreking van die begrippe AfrikANer, Afrikanerskap, Afrikanerdom en Afrikanerprototipe. Begripstatus word met klein hoofletters aangedui. Woordstatus word kursief aangedui.

3 Teen die agtergrond van die kompleksiteit van die begrip MORALITEIT impliseer negatiewe moraliteit iets anders as immoraliteit, 'n betekenisaspek wat nie in hierdie artikel beredeneer sal word nie. 
van dié simbole wat (afgeskaal) gebly het en gestigmatiseer is op grond van 'n negatiewe moraliteit ${ }^{3}$ wat daaraan toegeskryf is - sowel van binne as buite die gemeenskap wat tradisioneel as die Afrikanergemeenskap (vanuit bepaalde gesigspunte) bekend gestaan het. Die betekenis en rol van die Afrikaner is sistematies afgeskaal (ook as gevolg van die Afrikanerdiaspora) - maar bowenal het die afskaling van Afrikaans as hoëfunksietaal drasties en dramaties plaasgevind (teen 'n ongekende tempo) en meestal op grond van eksplisiete of implisiete oordeelvellinge met betrekking tot die morele status daarvan.

Op grond van die beskikbare statistiek tot op datum (2016) noem Van der Walt en Steyn (2016:1036) dat Afrikaansskole wat slegs Afrikaans as onderrigmedium gebruik het, sedert 2010 van 2521 afgeneem het tot 2 166. Hulle (idem.:1036) spreek die kommer uit dat "[a]s hierdie neiging voortduur, kan dit meebring dat Afrikaansmediumskole binne die volgende paar dekades mag verdwyn en die gevaar is dat Afrikaans as 'n gesproke taal in Suid-Afrika mag kwyn".

In 'n hoofstuk getitel "The rise and decline of Afrikaans as a public language and the possible demise of the Afrikaners" bespreek Giliomee (2019:304-325) die faktore en redes wat daartoe aanleiding gegee het dat Afrikaans as onderrigmedium by universiteite en skole afgeskaal is.

In hierdie artikel sal nie spesifiek uitgebrei word op Afrikaans as onderrigmedium nie. Dieperliggende semantiese en konseptuele veranderlikes word onder die soeklig geplaas.

Wat tot die afskaling (op alle vlakke) kon/kan bydra, het onder andere ook te doen (gehad) met besluitnemers se opvattings oor die status van Afrikaans binne bepaalde taalomgewings en oor die aard van (die Afrikaanse) taal. In 'n hoofstuk getitel "Afrikaans onder die ANCbewind (sedert 1994)" bespreek Steyn (2014:440-473) omvattend hoedat besluitnemers op verskillende vlakke die vroeëre status van Afrikaans afgeskaal het. Op regeringsvlak het dit onder andere neergekom op die samevoeging van universiteite met verskillende taalagtergronde. Op skoolvlak het dit gebeur dat onderwysdepartemente in sekere gevalle skole se voertaalbeleid verander het - meestal met die (morele?) motivering dat leerlinge nie hulle onderrigtaalkeuse geweier kan word nie, selfs indien hulle in ' $n$ minderheid is.

Binne die omgewing van die hoër onderwys het universiteitsrade as besluitnemers die rol en funksie van Afrikaans besleg. In sommige gevalle het dit ongesiens plaasgevind (soos in die geval van die Universiteit van Johannesburg), terwyl in ander gevalle (Universiteit van Stellenbosch) dit met stryd gepaard gegaan het. Hoedanig die hutswoorde \#Afrikaans must fall, gepaard met betogings, bygedra het tot die Universiteit van Pretoria se besluit om Afrikaans uit te faseer en Engels die primêre taal binne die betrokke universiteitskonteks te maak, sal net bespiegel kan word.

'n Taamlik algemene opvatting onder die algemene publiek wil dit hê dat taal slegs 'n kommunikasiemedium is. Verder van die waarheid kan 'n mens kwalik wees.

Taal is óók 'n kommunikasiemedium, maar taal is baie meer as dit: taal ontwikkel en struktureer kognisie (begrip); taal bind kultuur, sosiale samesyn, identiteit en nog talle ander aspekte van 'n bepaalde taalgemeenskap saam (of verdeel dit somtyds); taal is geïntegreer in emosionele en wilsgedrag; taal onthul en taal verbloem; taal bring dade tot stand, maar 'n taaluitdrukking is self ook 'n daad; taal maak gebruik van simbole, maar dien ook self as simbool. So sou 'n mens kon voortgaan om nog baie funksies van die komplekse verskynsel "taal" te beskryf.

Reeds in die vorige eeu het die toonaangewende taalkundige Ronald Langacker ${ }^{4}$ (1967:3) onder andere die volgende bewerings gemak ten opsigte van die aard van taal:

$4 \quad$ Langacker was een van die grondleggers van wat vandag bekendstaan as kognitiewe linguistiek.

Tydskrif vir Geesteswetenskappe, Jaargang 60 No. 4-2: Desember 2020 doi.10.17159/2224-7912/2020/v60n4-2a9 
- Taal is alomteenwoordig.

- Dit dring ons gedagtes binne, betrek ons verhoudings met ander - sluip selfs ons drome binne.

- Menslike kennis en kultuur is verhul in taal en word deur taal oorgedra.

- Gemeenskappe sonder taal is ondenkbaar.

Ten opsigte van die kompleksiteit van die begrip TAAL is hy van mening dat selfs professionele taalkundiges nie daarop kan aanspraak maak dat hulle taal ten volle verstaan nie.

Hy (ibid.:5) kom tot die gevolgtrekking: "Anyone who wishes to know and understand himself must come to understand in some measure the character of the linguistic system that plays such a fundamental role in his mental and social life."

Teen die voorgaande agtergrond word in hierdie artikel die ontmagtiging van Afrikaans as hoëfunksietaal in die verlede - en toenemend ${ }^{5}$ - op grond van onder andere bepaalde moraliteitsbeskouings ontleed.

\section{BETEKENISSE VAN DIE WOORD AFRIKAANS}

Natuurlik is Afrikaans ook dit wat alles hier bo genoem is. Daar moet egter in gedagte gehou word dat die woord Afrikaans binne verskillende kontekste heelwat verskillende betekenisonderskeidings oproep - soos dit ook die geval is met woorde vir die benoeming van ander tale en ander sake.

Verskillende gebruikskontekste bepaal of die betekenis van die woord veralgemeen word, gespesifiseer word, gemetaforiseer of gemetonimiseer word - normale taalkreatiewe prosesse. In sodanige gevalle staan die sentrale (prototipiese) betekenis van die woord in die sentrum en die ander gebruiksbetekenisse vorm 'n betekenisnetwerk daar rondom heen - ook genoem 'n radiale netwerk. Die konteks van gebruik bepaal die betekenisonderskeiding(s) wat geaktiveer word.

Die woord Afrikaans het nie 'n konkrete referent (saak) waarna dit in die reële wêreld verwys nie. As (ontologiese/fisiese) metafoor (AFRIKAANS IS 'N ENTITEIT ${ }^{6}$ ) kan dit beskryf word as 'n abstraksie wat dui op 'n versameling abstrakte grammatikale, betekenis- en ander strukture wat taalgebruikers in staat stel om sinvol betekenis te skep, oor te dra en te verstaan - 'n taal wat uit sewentiende-eeuse Nederlands (soos hoofsaaklik in die provinsie Holland gebruik) en onder invloed van ander tale in Suid-Afrika ontstaan en ontwikkel het. Dit sou as die sentrale (prototipiese) betekenis van die woord beskryf kon word. Die volgende gebruiksvoorbeelde dui op die entiteit-betekenisonderskeiding:

- "Afrikaans [ENTITEIT] in visier op transformasieberaad"

- "Verwarring het vandeesweek ontstaan oor die lot van Afrikaans [ENTITEIT] by die US"

Vergelyk Botha (2004:130-143) vir 'n volledige opgaaf en ontleding van voorbeelde.

Op 'n dieperliggende kognitiewe vlak word die taalgebruiker in staat gestel om 'n verskeidenheid taalmetafore te skep wat gebaseer is op enkele begripsmetafore (konseptuele metafore) en begripsubmetafore.

$5 \quad$ Vergelyk die hoofstuk "The rise and decline of Afrikaans as a public language and the possible demise of the Afrikaners" in Giliomee (2019).

$6 \quad$ Naas begripstatus wat met klein hoofletters aangedui word, word die status van konseptuele metafore dienooreenkomstig aangedui. 
Vergelyk onder andere hoedat die volgende taalmetafore (vergelyk Botha 2004:130-143) onderlê word deur die begripsmetafoor AFRIKAANS IS 'N LEWENDE ENTITEIT, tot stand gekom teen die agtergrond van die prekonseptuele skematiese ervaring van 'krag'/ 'beweging"?

- “Afrikaans mag nie die slagoffer van verkiesingspolitiek word nie ..."

- "Nog 'n begrafnisbrief vir Afrikaans"

- "(D)at Afrikaans sonder sy gekleurde sprekers nie sal oorleef nie ..."

- "(O)m Afrikaans die doodsteek te gee ..."

Oorvereenvoudig kan dit soos volg voorgestel word:

\begin{tabular}{|c|c|c|}
\hline \multicolumn{2}{|l|}{ Denke } & Taal \\
\hline \multicolumn{2}{|c|}{ Onbewuste betekenisprosessering: } & Taaluitdrukking van betekenis: \\
\hline \multicolumn{2}{|c|}{ geskied binne kognitiewe onbewuste ${ }^{8}$} & bewustelike proses \\
\hline Fase 1 & Fase 2 & Fase 3 \\
\hline Skema: & Begripsvorming: & Taaluitdrukkings: \\
\hline 'krag'/'beweging'9 > & $\begin{array}{l}\text { AFRIKAANS IS 'N } \\
\text { (LEWENDE) } \\
\text { ENTITEIT }>\end{array}$ & $\begin{array}{l}\text { "Nog 'n begrafnisbrief vir Afrikaans"; } \\
\text { "Afrikaans kry 'n skop in die tande"; ens. }\end{array}$ \\
\hline
\end{tabular}

\section{Diagram 1: Denke en taal}

\section{AFRIKAANS AS SIMBOOL}

Heg verweef met die betekenisverruiming of betekenisinperking van 'n woord - maar nie gekonvensionaliseer soos in die geval van die voorgenoemde betekenisonderskeidings nie - is die gebruiksfunksies van woord(e): esteties, informatief, faties - en vir hierdie bespreking, affektief en direktief.

Die affektiewe funksie van woorde (dikwels ook die assosiatiewe of emotiewe funksie genoem) dui daarop dat woorde se betekenisse "gelaai" word met inligting wat nie verwant is aan die konvensionele betekenisonderskeidings (woordeboekbetekenisse) van die betrokke woorde nie, maar wat bepaalde houdings van die gebruiker van die woorde weerspieël. In hierdie opsig hou dit direk verband met die direktiewe funksie van taal, naamlik beïnvloeding van die toekomstige gedrag van diegene tot wie die bepaalde taaluitdrukking(s) gerig word om hulle dienooreenkomstig die betrokke taalgebruiker se houdings, vooroordele, emosie, ensovoorts, te rig.

Die proses van affektiewe lading kan met 'n maansverduistering vergelyk word. In bepaalde gevalle - na gelang van die individu of groep se ervaringsraam (wat onder andere

7 Ons modelleer abstraksies op grond van ons liggaamlike ervaring van die werklikheid in terme van ' $n$ verbeeldingstruktuur wat saamgestel is uit beeldskematiese strukture. Sodanige beeldskematiese strukture hou verband met die menslike liggaamlike ervaring van onder andere ruimte, krag, sensasie en basiesevlakobjekte, aldus MacLaury (1991:65). Beeldskemas is dus nog nie taal nie en gaan konseptualisering vooraf.

8 Volgens Lakoff (1997:90) is "[t]he cognitive unconscious ... part of the mechanism of thought, by nature automatic and typically not subject to conscious control".

$9 \quad$ Skematisering word met enkel-aanhalingstekens aangedui. 
ideologie, godsdiens, kultuur, emosie, vooroordeel en binne hierdie konteks Afrikaansverwante ervarings insluit) - kan die sentrale betekenis van die woord gedeeltelik of algeheel verduister word, waar in laasgenoemde geval net 'n skynsel van die sentrale betekenis nog sigbaar mag wees. Sodanige verduistering van die sentrale betekenis van die betrokke woord (eintlik die begrip) kan daartoe bydra dat die betrokke woord (begrip) uiteindelik die status van 'n simbool verwerf. Dit beteken dat hoe meer sentrale betekenisonderskeidings binne die woord se verwysingspektrum betrek word, hoe minder "gelaai" is dit met affektiewe betekenis. Daarteenoor reduseer meer affektiewe betekenis die omvang van die woord se sentrale betekenis, en binne bepaalde (veral ideologiese) kontekste verkry die woord uiteindelik simboolstatus. Die emosionele en morele begronding van 'n simbool (vanuit 'n bepaalde ideologiese raamwerk) maak 'n rasionele gesprek daaroor dan uiters moeilik. Die semantikus Geoffrey Leech (1974:52/53) beskryf dit so: "(T)he greatest dangers to intelligent communication come with cases where the affective meaning becomes a major part of, if not the whole of, the message."

In gevalle waar Afrikaans negatief bejeën word, kom die simboolwaarde daarvan onder andere tot stand - en word in stand gehou - deur die woord (begrip) te stigmatiseer deur onder meer na Afrikaans te verwys as apartheidstaal, verdrukkerstaal, uitsluitingstaal en nog vele andere.

Ek noem enkele uitsprake in hierdie verband, met kursivering van die betrokke etikette.

- In 2019 reageer die Gautengse LUR vir Onderwys onder andere soos volg oor sy verskuiwing na die onderwysportefeulje: "Dit was ook die apartheidsregering wat my broers en susters op 16 Junie 1976 vermoor het bloot omdat hulle 'n apartheidstaal op hulle wou afdwing."

(https://www.netwerk24.com/Stemme/MyStem/ek-haat-nie-afrikaans-skryf-panyazalesufi-20190607-2)

- In 'n artikel getitel "Wees eerlik oor wat op die spel is in taaldebat" maak Sonja Loots (2015) beswaar teen valse aannames, ongetoetste stellings en growwe vooroordele soos dat Afrikaans as verdrukkerstaal beskryf word.

(https://www.netwerk24.com/Stemme/Menings/sonja-loots-wees-eerlik-oor-wat-opdie-spel-is-in-taaldebat-20151128)

- In 'n artikel ("Waarheen met Afrikaans?") praat prof. Michael le Cordeur (2015) van die "juk van apartheidstaal", verwysend na Afrikaans.

(https://www.netwerk24.com/Stemme/Aktueel/Waarheen-met-Afrikaans-20150616)

- Dr. Pieter Mulder (2014), in 'n artikel "Dink nuut oor plek vir Afrikaans", vat die dreigende klimaat waarin Afrikaans sy stryd om hoërfunksiebestaan moet voer, in die volgende punte saam:

- Afrikaans is 'n "witmanstaal".

- Die Afrikaanse debat is teen Engels.

- Afrikaans is nie 'n inheemse taal nie.

- Afrikaans moet as verdrukkerstaal gestraf word.

- $\quad$ Afrikaans sluit uit en gee aanstoot.

(https://www.netwerk24.com/Nuus/Dink-nuut-oor-plek-vir-Afrikaans-20140627)

Sedert 1976 - en steeds - sou dit dus nie vergesog wees nie om te beweer dat die aanslag vanuit bepaalde oorde teen Afrikaans - ook implisiet - onder andere (soms uitsluitlik) gerig word teen Afrikaans as simbool. Vanuit 'n bepaalde perspektief word 'n negatiewe simboolwaarde aan Afrikaans toegeken deur die abstraksie Afrikaans te personifieer ('n metafoor) 
as 'n dader (doener), en in die lig van beskuldigings teen Afrikaans wel 'n immorele dader. Houdings, vooroordele en emosies word dan assosiatief deel van die affektiewe betekenis van die woord - in so 'n mate dat dit die sentrale betekenis van die woord heeltemal verbleek. Verder aan in hierdie betoog word die morele implikasies daarvan uitgespel.

Die aanslag teen Afrikaans lê egter ook op 'n dieperliggende vlak, naamlik die vlak van die kognitiewe onbewuste - die vlak waarop die konseptuele metafoor beslag kry.

Die voorgenoemde pejoratiewe benoemings (etiketterings) van Afrikaans kan teruggevoer word tot die onderliggende konseptuele metafoor (begripsmetafoor) AFRIKAANS IS APARTHEID, wat sowel apartheidstaal, verdrukkerstaal, uitsluitingstaal en andere ondervang, juis omdat genoemde etikette waardeur Afrikaans beskryf word, tipiese kenmerke van apartheidsbelewenisse was.

Die konseptuele struktuur van 'n metafoor kan soos volg verduidelik word.

Vanuit 'n brondomein (denkruimte ${ }^{10}$ ) word betekeniservarings van 'n konsep gekarteer op 'n doelwitdomein (denkruimte). Vanuit 'n komplekse denkruimte (die sogenaamde generiese ruimte ${ }^{11}$ ) vind daar egter selektiewe invoer plaas van inligting uit sowel objektiewe as subjektiewe ervaringswêrelde (dus ook vooroordele, identiteite ens.) van die metafoorkonseptualiseerders na sowel brondomein as doelwitdomein. Die betekenis van die metafoor is dan geleë in 'n nuwe denkruimte wat as die versmeltingsruimte ("conceptual blend") bekend staan.

Vergelyk die onderstaande diagram ter illustrasie van die betrokke konseptualiseringsproses.

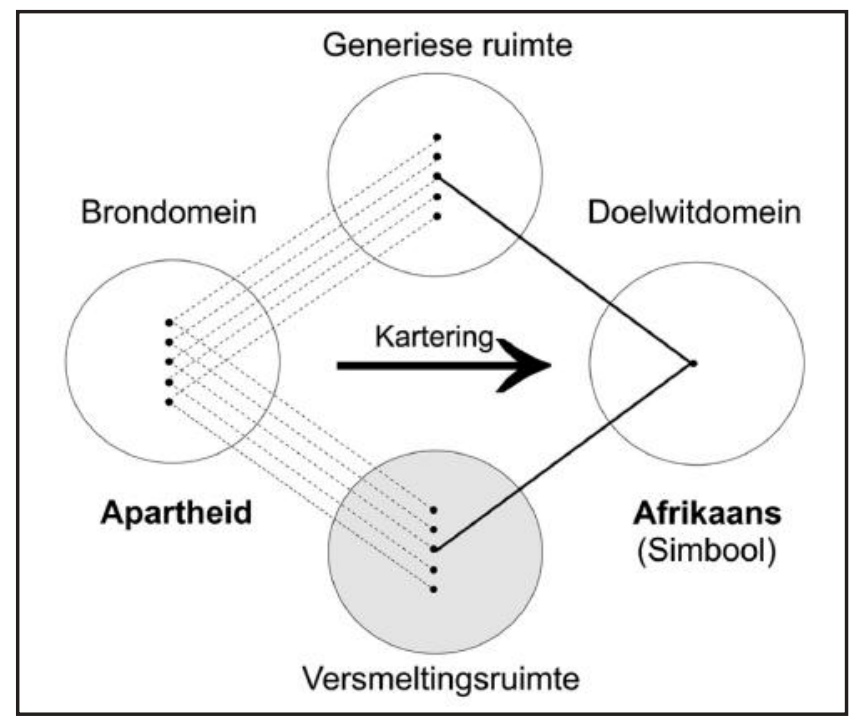

Diagram 2: $\quad$ Konseptuele invoer: verstaan van die metafoor AFRIKAANS IS APARTHEID

10 'n Denkruimte ("mental space") word deur Lakoff (1987:281) beskryf as "a medium for conceptualization and thought. Thus any fixed ongoing state of affairs as we conceptualize it is represented by a mental space".

11 Oakley (1998:357) beskryf die generiese ruimte as "a distinct mental space operating at a low level of description which can provide the category, frame, role, identity, or image-schematic rationale for crossdomain mapping." 
Die konseptuele invoer vanuit die generiese ruimte geskied nie eweredig nie, na gelang van die konseptualiseerders se relatiewe domeinervarings, wat natuurlik ook emotiewe belewenisse met betrekking tot die onderskeie konsepte insluit. In die geval van die konseptuele metafoor AFRIKAANS IS APARTHEID, waar die invoerdomein APARTHEID is en die doelwitdomein AFRIKAANS, vind sodanige oneweredige konseptuele invoer plaas. Die konsep AfrIKAANS, wat 'n baie ryk betekenisstruktuur het (vergelyk wat in die voorgaande bespreking oor taal gesê is), word in die onderhawige metafoor gereduseer tot simbool. Die omvattende kennisraam van APARTHEID wat gedrenk is in baie mense se affektiewe ervarings en ander se veroordelings, se konseptuele invoer word dus veral gekleur met intense emotiewe belewenisse, met die sentrale betekenis (proposisionele inhoud) heeltemal verhul - vir diegene wat taaluitdrukkings gebruik wat onderliggend op die konseptuele metafoor AFRIKAANS IS APARTHEID gebaseer is. Hierdie belewenisse word gevolglik op die begrip AfRIKAANS gekarteer. Binne die versmeltingsruimte ("conceptual blend") kan Afrikaans dus nie anders as negatief verstaan word nie.

Die krag van die onderhawige metafoor lê daarin dat dit neurologies ${ }^{12}$ vasgelê word, dus beslag kry binne neurologiese netwerke. Konstante herhaling van verskillende taalmetafore wat deur die betrokke konseptuele metafoor (AFRIKAANS IS APARTHEID) onderlê word, versterk die betrokke neurologiese metafoornetwerk in so 'n mate dat dit uiteindelik onnadenkend as "waarheid" aanvaar en beleef word, juis omdat die ervaring daarvan op die vlak van die kognitiewe onbewuste lê. Verder aan word meer gesê oor waarheid.

Vanuit ' $n$ ander hoek beskou, stem hierdie (subtiele?) strategie ooreen met wat Lakoff (2004) "framing" noem. Leech (1974:48) noem dit “conceptual engineering”. Ek beskryf dit as konseptuele inperking.

Lakoff (2004) beskryf in 'n publikasie getitel Don't think of an elephant! hoedat hy aan 'n bepaalde gehoor die volgende versoek gerig het: "Don't think of an elephant. Whatever you do, do not think of an elephant." Die versoek is natuurlik onuitvoerbaar omdat, soos hy (idem:3) dit stel: "Every word, like elephant, evokes a frame, which can be an image or other kinds of knowledge" en selfs "(w)hen we negate a frame, we evoke the frame." In die geval van taalmetafore wat beleweniseienskappe (kennisdomeine) van apartheid in verband bring met die etikettering van Afrikaans, en onderlê word deur die konseptuele metafoor AFrIKAANS IS APARTHEID, word die omvattende (kennis)raam van die woord apartheid by implikasie opgeroep en Afrikaans (as simbool - dus konseptueel ingeperk) daarby ingetrek en konseptueel versmelt.

Ter verdere verduideliking. Die woord olifant se referent is konkreet. Daarom is die betekeniseienskappe binne die begripsraam kontroleerbaar. Die woord Afrikaans roep egter 'n abstrakte en komplekse begripsraam op wat onkontroleerbaar is. Dit impliseer dat elke konseptualiseerder op grond van sy/haar script ${ }^{13}$-ervaring 'n bepaalde raam oproep by die hoor of gebruik van die woord Afrikaans. Diegene by wie die konseptuele metafoor AfriKaANS IS APARTHEID neurologies vasgelê is, sal waarskynlik meestal hierdie simbooleienskap begripsmatig ervaar.

Die effek en $\mathrm{krag}^{14}$ van sodanige etiketterings spreek vanself.

12 Lakoff (2009) beskryf die neurologiese kompleksiteit van die konseptuele metafoor in 'n artikel met die titel The neural theory of metaphor.

13 Dirven en Verspoor (1999:222) beskryf 'n script as "een geheel van voorstellingen die met een bepaalde scène samenhangen."

14 In Botha (2007) beskryf en verduidelik ek hoedat George Bush en Tony Blair in 2002 die konseptuele metafoor SADDAM HUSSEIN IS 'N TERRORIS geskep het (juis om 'n bepaalde begripsraam 
Omgekeerd kan simboolstatus natuurlik vir ander 'n positiewe emosionele betekenisinhoud inhou. Giliomee (2004:329) se verwysing na DF Malan wat in 1925, ná die verheffing van Afrikaans tot die status van ampstaal, verklaar het dat Afrikaans die "simbool ... van die volk, van sy bestaan (is)" bevestig 'n historiese simboolwaarde wat Afrikaans sedert daardie tyd gehad het. Die verband tussen simbool en emosie word ook onderskryf deur DF Malan se woorde ná die statusverhoging van Afrikaans tot amptelike taal, naamlik dat dit "'n voldoening aan die diepste gevoelens en hoogste aspirasies [beteken]", soos aangehaal deur Giliomee (2004:329).

Vir wie is die betrokke simboolstatus reg? Vir wie is dit verkeerd? Vir wie is dit goed? Vir wie is dit sleg?

Die morele basis van sodanige simbole is dus uiteenlopend en kompleks. Rasionele argumente ter beslegting van die teenstrydige emosionele belewenisse van 'n bepaalde simbool is uiters moeilik. Oor sodanige emosionele aanslag sê Leech (1974:50): "We only have a certain feeling that we are being called upon to respond emotionally, a feeling that may be difficult to put into words, and which may be even more difficult to counteract by argument."

Alhoewel die neurowetenskaplike Antonio Damasio (1994:xxii) die problematiek van rasionele versus emosionele 'argumente' erken ("emotions and feelings can cause havoc in the processes of reasoning under certain circumstances"), is hy van mening dat "emotions and feelings may not be intruders in the bastion of reason at all: it may be enmeshed in its networks: for worse and for better". Hiermee wil Damasio beklemtoon dat emosie en rasionaliteit nie as afsonderlike komponente binne die menslike psige bestaan nie. Dit beteken egter ook dat rasionaliteit (óf irrasionaliteit) en emosie in 'n relatiewe verhouding tot mekaar staan (of met mekaar geïntegreer is), én dat dit van persoon tot persoon en van groep tot groep verskil - ook wat hulle (morele/immorele) belewenisse en strategieë betref.

\section{AFRIKAANSONTMAGTIGING}

Soos in die onlangse verlede bevind Afrikaans hom steeds in die sentrum van besluitneming wat hom gestroop laat van funksies wat voorheen as vanselfsprekend gegeld het. Afrikaans is/word ontmagtig - én die moedertaalsprekers van Afrikaans is/word ontmagtig.

Ontmagtiging dui hier op die doelbewuste (geïnstitusionaliseerde) afskaling van die kollektiewe en individuele gebruiksfunksies van Afrikaans binne verskillende taalomgewings - taalomgewings waarbinne Afrikaans voorheen dominante status gehad het, maar ook taalomgewings waarbinne Afrikaans gelyke status met Engels gehad het.

Sodanige ontmagtiging vind op twee vlakke plaas.

Eerstens word Afrikaans (as abstraksie) ingeperk met betrekking tot die hoër funksies van gebruik en ontwikkeling, dít wat Afrikaans onder andere akademiese taal, wetenskapstaal, regstaal, kanseltaal, tegnologietaal (vergelyk maar Microsoft se erkenning van Afrikaans binne Microsoft-programmatuur) en nog vele ander gemaak het. Om 'n metafoor te gebruik, sou 'n mens kon sê: 'n Lewende taal word sy suurstof ontneem.

In die tweede plek word moedertaalsprekers van Afrikaans as moedertaal-individue binne sodanige omgewings (die realiteitsvlak) daarvan weerhou om Afrikaans te ervaar en te gebruik. Soos reeds genoem, is Damasio van oordeel dat daar 'n intrinsieke integrerende verhouding tussen rasionaliteit en emosie bestaan. Moedertaalontmagtiging impliseer dus dat (van) die

op te roep by die vermelding van die woorde Saddam Hussein) om 'n oorlog teen Irak te regverdig

- 'n metafoor wat later geblyk vals te gewees het.

Tydskrif vir Geesteswetenskappe, Jaargang 60 No. 4-2: Desember 2020

doi.10.17159/2224-7912/2020/v60n4-2a9 
moedertaalspreker ${ }^{15}$ se emosioneel-rasionele ontwikkeling binne gevestigde ontwikkelde en ontwikkelende emosioneel-kognitiewe strukture ingeperk word.

Enige doelbewuste besluit oor die status van 'n bepaalde taal sny dus diep in die wese van taal as abstraksie (veral ook wat sy voortgesette ontwikkeling betref), maar ook in die wese (en ontwikkeling) van menige individuele moedertaalspreker van daardie taal. Maar besluite oor taal is in die verlede geneem, word steeds geneem en sal in die toekoms ook geneem word.

Besluitnemers se dilemmas is veelvuldig:

- Besluit ons op grond daarvan dat Afrikaans (as abstraksie) se formele (hoër) gebruiksfunksies sodanig gekwyn het (met die veronderstelling dat Engels tog maar die verstektaal in Suid-Afrika is) dat ons die formele gebruik daarvan binne 'n bepaalde omgewing kan afskaal, uiteindelik totaal reduseer? Watter morele implikasies hou dit in?

- Besluit ons oor Afrikaans se status op grond van die negatiewe of positiewe simboolwaarde wat daaraan geheg word? Wat is die morele implikasies van so 'n besluit?

- Wie se 'waarheid' oor die ervaring van Afrikaans aanvaar ons as die basis van ons besluit, en met watter morele gevolge - of word die taalbepaling binne die SuidAfrikaanse Grondwet as 'dié waarheid' aanvaar, met die stipulasie "redelikerwys doenlik" (met verwysing na onderrigmedium van keuse) as morele skuiwergat?

Werklikheidskwessies ten opsigte van Afrikaans waarmee besluitnemers ook moes/moet rekening hou, is van die sake wat reeds in die openbare domein gedebatteer is en word, sake wat morele implikasies inhou. Enkele sake word genoem.

Indien dit 'n natuurlike verdringing van Afrikaans deur Engels was, iets wat juis aangestig kan word deur doelbewuste ontmagtiging van Afrikaans, sou die moraliteit van ontmagtiging nie so duidelik in die kollig gestaan het nie. Dan sou die moraliteit van statistiese regverdiging beredeneer moes word. Hierdie bespreking word nie daaraan gewy nie.

As moralitieitskwessie het die saak egter ook 'n ander kant. Argumente ter regverdiging van Afrikaansontmagtiging hou in dat Afrikaans mense uitsluit; Afrikaans word dus as 'n obstruksie (blokkasie) beskou, 'n opvatting wat toenemend veld wen.

Aansluitend by bogenoemde argument word toenemend geredeneer dat Afrikaans in die pad van transformasie staan. Dit is dus ook nodig om binne hierdie konteks aandag aan die begrip TRANSFORMASIE te skenk. Dit word verder aan gedoen.

'n Verdere argument word gevoer (binne byvoorbeeld die tersiêre sfeer) dat moedertaalsprekers van Afrikatale Engels as onderrigtaal kognitief uitdagend vind, en dit dus net regverdig sal wees dat Afrikaans-moedertaalsprekers dieselfde uitdaging gebied word - dus 'n morele kwessie. Engels-moedertaalsprekers word dan geag neutraal te wees binne hierdie morele spanningsveld.

15 Om veralgemenende stellings ten opsigte van moedertaalsprekers as sodanig te maak, is natuurlik misleidend (veral ook wat leeromgewings betref) omdat dit nie rekenskap gee van die feit dat daar intelligensieverskille, opvoedingsverskille, kultuurverskille, motiveringsverskille en ander persoonlikheidsverskille bestaan wat elkeen se ervaring van 'n spesifieke taalsituasie verskillend maak nie. Dit behoort ook as 'n belangrike veranderlike beskou te word wanneer daar sonder meer taalbesluite op grond van statistiese data geneem word. 
Die moraliteitskwessie word verder gekompliseer indien die kunsmatige spanning wat tussen Afrikaans en Engels geskep word, opgeweeg word teen die werklike "amptelikheid" van die ander Afrikatale. Hierdie saak sal ook nie verder bespreek word nie.

Moraliteitskompromisse is natuurlik ook moontlik. Binne die hoër onderwys verteenwoordig tolking byvoorbeeld sodanige kompromis. Dit impliseer dat 'n bepaalde individu of groep die handeling as nie-reg en nie-goed, óf reg maar nie goed nie, óf goed maar nie reg nie, ervaar, maar ter wille van versoening of ordelike funksionering en gedeelde doelwitte die ervaring daarvan versag. Uiteraard sal emosie hier in gedrang kom, dikwels die krag wat die moraliteitspendulum in beweging hou.

'n Moraliteitskompromis wat uit 'n bepaalde oord (die kantoor van die Gautengse LUR vir Onderwys) as immoreel ervaar word, is die stigting van Akademia, 'n privaat verskaffer van hoër onderwys in Afrikaans, wat tot stand gekom het weens druk op voormalige Afrikaanse tersiêre instellings om in Engels te onderrig in plaas van Afrikaans.

Uit dieselfde oord, die kantoor van die Gautengse LUR vir Onderwys, is daar ook beswaar gemaak teen 'n onlangse uitspraak van die appèlhof dat die taalbeleid van Unisa, wat die afgelope vier jaar Afrikaans as onderrigtaal uitgesluit het, ongeldig is. Die versoek uit hierdie kantoor was dat die minister van hoër onderwys teen hierdie uitspraak moet appèl aanteken, want "as ons dit nie doen nie, sal ons alle tale ondermyn. Alle tale is gelyk en daar is geen super-taal nie". Nogal. (vergelyk https://www.netwerk24.com/Nuus/Onderwys/lesufi-vaaruit-teen-appelhof-uitspraak-oor-unisa-taalbeleid-20200721).

Dit is nie moeilik om die vergeldingskema, waaroor later meer, hier in te lees nie.

\section{MORALITEIT EN ONTMAGTIGING}

Uit die voorgaande uiteensetting blyk dit dat die begripskonfigurasie MORALITEIT 'n paar dinge impliseer: die daad (om Afrikaans se status en gebruik af te skaal) word as reg óf verkeerd, goed óf sleg beoordeel; die nie-daad (om die status quo ten opsigte van Afrikaans en Engels te handhaaf) word as reg óf verkeerd, goed óf sleg beoordeel; die beoordeling vind plaas op grond van verskillende individue of groepe se agtergrondbeskouings, wat onder andere berus op unieke of gedeelde ervarings. Binne die kognitiewe taalkunde staan hierdie kennisnetwerk bekend as 'n konseptuele raam (begripsraam) - 'n aspek wat ook in 'n vorige afdeling aandag geniet het, wel binne 'n ander konteks - wat verskillende ervaringsdomeine met mekaar skakel wanneer ' $n$ bepaalde begrip eksplisiet (by wyse van 'n bepaalde taaluitdrukking) of implisiet ervaar word. Die ervaringsdomeine mag feite, halwe waarhede, mites, kulturele waardes en norme - en nog meer - insluit. Dit sluit nou aan by die individu of groep se belewenis van relatiewe waarheid - wat reeds in die voorgaande betoog genoem is en nie hier in besonderhede bespreek kan word nie. Hier kan net genoem word dat wat waarheid (feitelikheid) betref, minstens drie vlakke van waarheid onderskei kan word, naamlik:

- $\quad$ universele waarheid, byvoorbeeld Die aarde wentel om die son - vir alle bekende plekke en tye waar, terwyl die ontkenning daarvan vir alle bekende plekke en tye vals is;

- $\quad$ objektiewe waarheid, byvoorbeeld Die son skyn vandag of Die son skyn nie vandag nie - waar of vals na gelang van die tyd- en plekomstandighede;

- $\quad$ etiese oordeel, dikwels as kategoriese waarheid aangebied ten spyte daarvan dat die waarheid daarvan moeilik objektief verifieerbaar is, byvoorbeeld Afrikaans staan in die pad van transformasie. 
Die grens tussen die waarheid en die leuen, synde abstrakte begrippe, is wasig. In die kognitiewe taalkunde word daar van "fuzzy boundaries" gepraat. Dit beteken dat kategorie-eienskappe van 'n bepaalde lid van 'n kategorie sodanig is dat dit maklik tot enigeen van twee kategorieë kan behoort. Daarom kan bepaalde bewerings/stellings kwasi-waarhede wees, ook halfwaarhede, verskuilde waarhede, mitiese waarhede en ander. Dikwels lê die grens daarvan baie na aan die leuen - maar dit is nog nie 'n leuen nie. Van die metafore wat deur die konseptuele metafoor AFRIKAANS IS APARTHEID onderlê word, val binne hierdie kategorie - ook die onderhawige konseptuele metafoor self.

Die bespreking ${ }^{16}$ geskied verder met inagneming van wat Lakoff en Johnson (1999:3) as die drie belangrikste onlangse ontdekkings van die kognitiewe wetenskap beskou, naamlik: "The mind is inherently embodied. Thought is mostly unconscious. Abstract concepts are largely metaphorical."

Teen hierdie agtergrond word moraliteit primêr gesien as die bevordering van menslike welstand, veral dié van ander. Daarom is dit nie vreemd nie dat sogenaamde "folk-theories" - binne hierdie konteks die fenomenologiese vlak van waarheidservaring - ten opsigte waarvan menslike welstand beoordeel word, as die begronding van morele metafore geld. In ooreenstemming hiermee is een van die mees basiese begripsmetafore op grond waarvan moraliteit verstaan word, die sogenaamde "MORAL ACCOUNTING"-metafoor - waarvan die taalmetafoor "morele bankrotskap" onder andere getuig.

Die beliggaamde oorsprong van hierdie metafoor is nie moeilik agterhaalbaar nie. Daar is vroeër daarop gewys dat beeldskematiese strukture 'n verbeeldingstruktuur onderlê wat begripsvorming moontlik maak - voordat dit 'n taaluitdrukking word. Vergelyk byvoorbeeld hoedat die volgende uitdrukkings almal verstaan word in ooreenstemming met 'n ewewigsverhouding, geskoei op die menslike liggaamlike ervaring van balans: "in die reine bring", "'n geskil besleg", "skuld vereffen", "opoffer vir", "die orde herstel”, "'n daad of optrede vergeld", "verantwoording doen van", "verantwoordelik hou vir" en "ongeregtighede regstel". Kognitief dieperliggend is die "MORAL ACCOUNTING"-begripsmetafoor op sodanige 'ewewig'-beeldskema gebaseer.

Die bogenoemde uitdrukkings is by implikasie die manifestasie van 'n aantal basiese ervaringskemas op grond waarvan die metafoor MORELE BOEKHOUDING (DIE MORELE BOEKE BALANSEER) verstaan word. Dit is belangrik om hier te benadruk dat die begrip 'metafoor' hier nie na taal verwys nie - dit is ' $n$ dieperliggende begripservaring wat deur verskillende taaluitdrukkings gemanifesteer word, soos wat dit byvoorbeeld in die voorafgaande paragraaf geillustreer is.

Lakoff en Johnson (1999:293-298) onderskei onder andere die volgende (intermediêre) skemas wat die betrokke metafoor onderlê: 'morele wisselwerking', 'retribusie/vergelding', 'restitusie/herstel', 'altruïsme', 'die-ander-wang-draai-ervaring', 'karma' en 'billikheid'. Dit is nie die bedoeling om die bepaalde skemas hier in besonderhede te bespreek nie. Wat egter wel op gewys moet word, is die feit dat morele gedrag, deur watter skema ook al talig gerealiseer in die betekenis van die metafoor DIE MORELE BOEKE BALANSEER, deur twee beginsels onderlê word (aldus die genoemde outeurs), naamlik:

- Morele optrede veronderstel die gee van iets met positiewe waarde, terwyl immorele optrede die gee van iets met 'n negatiewe waarde impliseer.

16 Die argumente in die volgende uiteensetting is ook vervat in Botha (2020). 
- Morele optrede vooronderstel dat morele skuld vereffen sal word, terwyl immorele optrede die ontduiking van morele skuld impliseer.

Die beginsels klink goed, maar moraliteit met betrekking tot die MORELE-BOEKE-BALANSEERmetafoor raak problematies in die geval van negatiewe optrede, soos wanneer retribusie of vergelding ter sprake is. Deur iemand byvoorbeeld te na te kom, word die lydende party onder die morele verpligting geplaas om dienooreenkomstig negatief teenoor die gewer van die negatiewe handeling op te tree om die "morele boeke te balanseer" - om die morele skuld te vereffen. Tree die lydende party nie sodanig op nie, word hy/sy voor die morele dilemma gestel dat hy/sy die morele skuld nie vereffen het nie. Dit kan natuurlik tot die rekursiwiteit van immoraliteit in die naam van moraliteit lei. Die kompleksiteit van sodanige morele problematiek is treffend in die drama Germanicus (deur NP van Wyk Louw) raak te lees. Germanicus word voor die morele keuse gestel om te kies: óf immorele optrede teenoor Tiberius, ter wille van 'n morele verpligting teenoor die volk, óf immorele optrede teenoor die volk (gevolglik moreel teenoor Tiberius) in die naam van moraliteit, om die immoraliteit van verraad te ontduik - in sy eie woorde: "Ek is getrou. Ek is aan trou gewoond" (Germanicus, 1961:9). Germanicus kan immoraliteit nie ontsnap nie. Hy kan die morele boeke nie laat klop nie. ${ }^{17}$

\section{WAARHEID, MORALITEIT EN SUID-AFRIKA}

Om die hedendaagse posisie van Afrikaans in perspektief te stel, is dit nodig om dit op te weeg teen die historiese en kontemporêre omstandighede in Suid-Afrika.

Binne die historiese en hedendaagse kompleksiteit van 'n diverse Suid-Afrikaanse samelewing is daar woorde wat binne hulle betekenisse 'n moraliteitsdimensie "ingebou" het. Vergelyk byvoorbeeld woorde soos waarheid, menslikheid, regstelling, transformasie, mag, bemagtig, ontmagtig, rassisme, kolonialisme en ander, woorde waarvan die moraliteitisdimensie in die geval van sommiges 'n noue historiese verbintenis met die gestigmatiseerde woord apartheid het. In sodanige gevalle het ons inderwaarheid nie met woordbetekenis te doen nie, maar met begripsbetekenis, gedagtig daaraan dat begripsbetekenis meer inhou as die konvensionele woordeboekbetekenis van 'n woord, soos vroeër vermeld. Vergelyk maar hoedat die woord korrupsie binne die Suid-Afrikaanse konteks verskillende begrippe aktiveer - én natuurlik bepaalde moraliteitskemas. Daar is byvoorbeeld al die opmerking gemaak dat die woord korrupsie Westerse opvattings verteenwoordig - maar nie genoem dat die begrip daarvan geweeg moet word teen 'n Westers georiënteerde grondwet nie.

Die jaar 1994 en daarna het vir baie Suid-Afrikaners bepaalde waarheidservaringe gebring. Verhale vertel tydens die verrigtinge van die Waarheid-en-versoeningskommissie het die waarheid baie gesigte gegee, veral wat 'menslikheid' betref. Soos reeds genoem, hou moraliteit ten nouste verband met die bevordering van menslike welstand, veral dié van ander, dus: menslikheid!

Talle veronderstelde waarheidsverkondigers se geloofwaardigheid het in gedrang gekom omdat 'n omkeer van die waarheid valsheid impliseer; maar dit het ook 'n agterdog gebring ten opsigte van wat in die toekoms as waarheid mag geld.

Op 'n ander vlak het nuwe besinning oor waarheid 'n wye spektrum emosionele ervaringe teweeggebring, en gepaard hiermee 'n profilering van wat as reg en verkeerd gegeld het - én

17 In Botha (2020) word die moraliteitskompleksiteit waaraan Germanicus blootgestel word, in besonderhede bespreek. 
wat in die toekoms as reg en verkeerd behoort te geld. In die sentrum hiervan het die beleid van afsonderlikheid gestaan. As 'n moraliteitsopenbarende krag is dit gedra deur die gebruik van die uiters gestigmatiseerde woord apartheid, en bejeën as 'n manifestasie van die omvattender gestigmatiseerde begrip RASSISME. Die praktyk daarvan is oor ' $n$ wye spektrum as immoreel ervaar, beskryf, bely en teengestaan.

Vir baie vorige ondersteuners van apartheid het die nuwe bedeling die intrinsieke morele spanning tussen wat as reg en goed voorgehou is in verhouding tot 'n inherente gevoel van wat verkeerd en sleg is, opgehef. By ander is die spanning tussen "reg, maar nie goed nie" (dus verkeerd) verbreek. Nog ander was verlig dat dit wat as verkeerd en sleg beskou is, uit die weg geruim is. Dit was nie ongewoon om dikwels te hoor dat mense 'n gevoel van morele bevryding ná 1994 beleef het nie. En dan was en is daar ook diegene wie se morele sintuig weinig aangeraak is.

Ná 1994 moes baie Suid-Afrikaners met 'n gekneusde waarheidservaring die morele kompas verstel. Die impak wat die beleid van afsonderlikheid op individue se totale menswees gehad het, kan nie geringgeskat word nie. Opwellings van onrus, geweld, insidente, verwyte, teregwysings en vermanings met rassistiese ondertone verraai 'n rasstempel ("racial imprint") waarvan baie - oor die hele spektrum - nog nie ontdaan is nie. Dit kan onder andere teruggevoer word na die feit dat die ontwikkeling van rassisme (in die vorm van afsonderlike ontwikkeling) een van die mees basiese ruimtelike ervaringskemas betrek, naamlik in die geval van die Suid-Afrikaanse samelewing die doelbewuste ideologiese objektivering van die 'proksimiteitskema'. Die skematiese ervaring van nabyheid en verwydering word al heel vroeg in die kind se ontwikkeling van taal gemanifesteer deur nabyheidswoorde en -uitdrukkings soos hier en hierdie $X$ en afstandswoorde en -uitdrukkings soos daar en daardie X. Taylor (1995:134) wys tereg daarop dat die "degree of emotional involvement and the possibility of mutual influence are understood in terms of proximity". Die beleid van afsonderlikheid het in sy wese die gewaande morele regverdiging vir distansiëring gedra.

\section{TRANSFORMASIE ${ }^{18}$}

In 1996 word Die Grondwet van die Republiek van Suid-Afrika aangeneem. In die Aanhef word onder andere gestipuleer dat dit daarop gerig is om "(d)ie verdeeldheid van die verlede te heel en 'n samelewing gegrond op demokratiese waardes, maatskaplike geregtigheid en basiese menseregte te skep". Die suiwerheid van die morele motiewe wat deur hierdie woorde gedra word, staan bo verdenking.

Om te kan "heel" en te kan "skep", moet meganismes egter in werking gestel word - en die gebruik van meganismes veronderstel dat iemand of iets as agent van die handeling met behulp van die betrokke meganismes (instrumente) moet optree. En watter beter woord is daar - wat deur sy inhoud die voorgenoemde veronderstellings dra - as transformasie? 'n Ontleding van die betekenisinhoud (betekeniskonfigurasie) van die woord transformasie onthul die opeenvolging van die volgende betekeniseienskappe wat in sowel die letterlike as metaforiese gebruik van die woord 'n betekenisgestalt vorm: 'n bron instigeer 'n handeling; die handeling veroorsaak verandering van 'n konkrete of abstrakte objek; 'n entiteit tree as agent van die verandering op; die agent het mag oor instrumente vir verandering; die bron voorsien die instrument van mag; die verandering volg 'n roete; die roete vir verandering geskied vanaf 'n

18 Vergelyk Botha (2004) en Botha (2007) vir 'n omvattender bespreking van die begrip TRANSFORMASIE. 
vertrekpunt na 'n bestemming; die verandering kan oor 'n grens geskied - of dit kan 'n hele domein omvat; die verandering word binne 'n bepaalde tydsbestek voltrek; die verandering het 'n nuwe struktuur tot gevolg.

Die betekeniskonfigurasie van die woord transformasie kan getoets word teen die agtergrond van die oorgang van die amptelikheid van twee tale na die amptelikheid van elf tale.

Binne die Suid-Afrikaanse samelewing dien die Grondwet byvoorbeeld as die wesensbron ten opsigte van onder andere die amptelike tale (geïmpliseerde handelinge ten behoewe van verandering). Wetgewing bepaal dat twee amptelike tale vervang word met elf amptelike tale (agent van verandering). Verskillende regeringsinstansies en ander institusionele instansies tot op die vlak van skoolrade word bemagtig (instrumente). Die roete vir die omskakeling van 'n tweetaal-amptelikheid na 'n elftaal-amptelikheid geskied via verskillende gemagtigde instansies. Die tydsbestek vir die voltrekking van die verandering binne die Suid-Afrikaanse samelewing is vaag en in bepaalde kontekste nog onafgehandel. Die nuwe struktuur impliseer 'n elftaal-amptelikheid.

Die praktyk het die onhaalbaarheid en onpraktiese implikasies van hierdie transformasie duidelik uitgewys, met die gevolg dat 'n dualiteit ontstaan het tussen Engels aan die een kant en die ander tale (gesamentlik) aan die ander kant - met Engels dan die de facto amptelike taal.

Dit is nie vreemd dat die betekeniskompleksiteit van die woord transformasie - veral wat sy metaforiese gebruik betref - talle interpretasies tot gevolg gehad het nie. Mense se reële ervaring van die begipsinhoud daarvan het ook talle nuwe metaforiese betekenisinhoude daaraan toegevoeg, soos die volgende aangetekende begripsmetafore ${ }^{19}$ (deur taalmetafore vergestalt) byvoorbeeld aandui: transformasie is 'N LEWENDE ORGANISME, ... 'N BEWEGENDE ORGANISME, ... 'N MiLITÊRE HANDELING, ... 'N BEPERKENDE ENTITEIT, ... 'N BEWEGENDE ENTITEIT, ... 'N TEENSTANDER, ... 'N KRAG, ... 'N ALLESOMVATTENDE HANDELING, ... 'N OPOFFERENDE AKTIWITEIT, ... 'N Voertuig, ... 'N Geïnstigeerde handeling, ... 'N ROETE, en nog talle ander.

Die betekeniskompleksitieit van die woord transformasie spruit onder andere uit die betrokke woord se superordinaatstatus binne 'n leksikale betekenisveld. 'n Superordinaat staan in 'n óf...óf-implikasieverhouding tot sy hiponieme. ${ }^{20}$ In die onderhawige geval beteken dit transformasie as superordinaat impliseer (vanuit bepaalde beheersende punte) óf regstelling, óf (swart) bemagtiging, óf (wit) ontmagtiging, óf ..., óf ... ensovoorts, as hiponieme binne die kontemporêre Suid-Afrikaanse samelewing. Omgekeerd beteken dit dat talle hiponieme binne die bepaalde politieke en ideologiese werklikheid "gekies" kan word om op grond van 'n eensydige implikasieverhouding die begrip TRANSFORMASIE te impliseer en as die woord transformasie te benoem. Omdat die betekenis van die woord transformasie as superordinaat op 'n hoër en abstrakter (algemener) kognitiewe vlak as die betrokke woord se hiponiembegrippe ervaar word, word die gebruik daarvan semanties "leeg": hoe meer sake die woord (kan) benoem, hoe minder "beteken" die woord. Daarom juis laat dit as benoeming 'n verskeidenheid hiponimiese begrippe toe, na gelang van watter begrip die spreker ook al mag kies om met die woord transformasie te benoem. Dit is dus nie vreemd dat transformasie vir verskillende mense verskillende dinge kan beteken nie.

19 Vergelyk Botha (2004) en Botha (2007).

20 Die woord blom is byvoorbeeld 'n superordinaat van die hiponieme roos, angelier, dahlia ensovoorts. Dit beteken roos impliseer blom, angelier impliseer blom, dahlia impliseer blom, ... ensovoorts. Omdat die implikasieverhouding egter eensydig is, beteken dit omgekeerd dat blom óf roos, óf angelier, óf dahlia, óf ... ensovoorts impliseer. 
Superordinaatgebruik is 'n baie algemene gesprekstrategie wat oor die ganse spektrum van taalgebruik voorkom. Dit stel die spreker in staat om vaag of algemeen te benoem na gelang van die kontekstuele omstandighede - maar as sambreelterm kan 'n spesifieke metaforiese gebruik daarvan binne bepaalde omstandighede kognitief dieper as die hiponiemvlak die prekonseptuele kragbeeldskema 'kragblokkasie' aktiveer in die metaforiese taaluitdrukking "Afrikaans staan in die pad van transformasie". Dienooreenkomstig aktiveer die metaforiese uitdrukking "Afrikaans sluit uit" die (rudimentêre) prekonseptuele kragbeeldskema 'teenkrag'. Herhaalde en voortdurende gebruik van metafore wat die bepaalde kragskemas aktiveer, bewerkstellig dat die betrokke skemas op die taalbewussynsvlak geobjektiveerde ${ }^{21}$ "werklikhede" word. Indien Lakoff en Johnson (1999:3) se beskouing dat "(t)he mind is inherently embodied" - en dat abstrakte denke dienooreenkomstig gerig word - in ag geneem word, volg hieruit dat sodanige uitsprake as "liggaamlike betekenisbelewenisse" ervaar kan word. Taalstrategies is hierdie soort metafore van die kragtigste meganismes wat teen Afrikaans gebruik kan word - ook op grond van die morele gewig wat die begrip TRANSFORMASIE binne die Suid-Afrikaanse konteks dra.

Aansluitend hierby kan genoem word dat die "liggaamlike betekenisbelewenis" van die betrokke metafoor versterk word deur wat Sweetser (2003:16) gebare-metafore noem: "Examination of language and gesture side-by-side provides strong added support for the cognitive reality of mental space structures. Gesture maps Real Space ... onto mental spaces of expressed content." Betogings voorheen (soms gewelddadig) teen die gebruik van Afrikaans binne bepaalde onderrigsfere - gepaard met die eksplisiete of implisiete taalhandeling(e) van 'n eis - het kollektief (ongenuanseerd as verruimde gebare-metafore) as die liggaamsmetafoor VERSET opgetree. Dit het onder andere tot stand gekom op grond van die prekonseptuele ervaringskema 'teenkrag', 'n subordinaat van die kragbeeldskema 'krag'. In sodanige gevalle is die aanslag teen Afrikaans drieledig van aard: gedra deur 'n taalmetafoor, 'n liggaamsmetafoor en taalhandelinge! En taalhandelinge (soms gepaard met geweld-liggaamsmetafore) rig diegene tot wie dit gerig is - subtiel of kras - se toekomstige gedrag. ${ }^{22}$

Alhoewel die letterlike gebruik van die woord transformasie neutraal is ten opsigte van moraliteit, word by implikasie 'n aantal integrerende moralitetsbeginsels binne die SuidAfrikaanse konteks tot die begripsinhoud daarvan toegevoeg deur onder andere die bogenoemde metaforiese uitbreidings - maar veral ook omdat die woord transformasie moet dien as sambreel vir moraliteitsimpliserende begrippe soos vervat in onder meer 'regstellende aksie', 'swart bemagtiging', 'gelyke geleenthede' en ander (soos reeds genoem) - wat die moraliteit van billikheid as gemeenskaplike onderbou behoort te hê. Daarom word die frase "verbind tot transformasie" beskou as 'n morele verbintenis. Om nie tot transformasie verbind te wees nie, sou dan immoreel wees. Maar transformasie deur wetgewing afgedwing verander natuurlik die aard van die moraliteitservaring by bepaalde individue en groepe.

Die kompleksiteit van die billikheidskema wat die begrip 'transformasie' onderlê, maak die uitlewing daarvan nie eenvoudig nie - en die toenemende wekroep dat Afrikaans in die pad staan van transformasie (transformasie dus blokkeer) verhef 'n onderliggende ervaringskema tot 'n geobjektiveerde inhoudlose realiteitservaring, dié soort propagandataal wat deur

$21 \quad$ Langacker (1990:7) gebruik die terme geobjektiveerde en gesubjektiveerde konstruering om aan te dui dat "an entity construed subjectively is implicit and hence non-salient ... whereas the objectively-construed entity is salient by virtue of being placed onstage as the focus of attention." Dit was nie soseer die taalmetafoor \#fees must fall (vanaf Oktober 2015) wat die relatiewe sukses (?) van betogings teen universiteitsfooie bewerkstellig het nie. Die resultaat van die betogings was eintlik die gevolg van die eksplisiete vergestalting van die liggaamsmetafoor VERSET. 
emosie rasionaliteit verswelg. Hierdeur word die begrip TRANSFORMASIE die middelpuntvliedende $\mathrm{krag}$, met in die sentrum daarvan die simbool Afrikaans, met 'n menigte pejoratiewe verwysings daaraan vasgedruk - in so 'n mate dat menings, opvattings en vooroordele uiteindelik as objektiewe feite aanvaar word. Dermate kom inleidingsinne soos die volgende al hoe meer dikwels voor wanneer negatiewe simboolwaardes aan die woord Afrikaans gekoppel word: "Soos ons almal weet, het Afrikaans ..." - en dan volg die aanklag. Die simbool Afrikaans, die abstraksie Afrikaans - en alle eksponente van Afrikaans - word dus in 'n permanente immorele defensiewe staat geplaas.

Sou 'n meer genuanseerde waarheid enigsins sodanige immoraliteitsbeskouing kon versag? In hierdie stadium van Afrikaansaftakeling kan dit moeilik voorsien word, tensy besinning en besluitneming op die billikheidskema gebaseer is.

\section{DIE BILLIKHEIDSKEMA}

Soos by implikasie genoem, betrek die begrip TRANSFORMASIE die moraliteitskema 'billikheid', soos uitgestippel in die Handves van regte binne Die Grondwet van die Republiek van SuidAfrika. In subartikel 9(5) word gestipuleer dat "(d)iskriminasie ... onbillik (is), tensy daar vasgestel word dat die diskriminasie billik is". Dit laat die weg oop vir "onbillike" praktyke in die naam van billikheid - want wie se oordeel bepaal billikheid? Encarta World English Dictionary (elektroniese kopie) beskryf diskriminasie byvoorbeeld onder andere as "UNFAIR treatment of one person or group" terwyl Webster's New World Dictionary \& Thesaurus (elektroniese kopie) se beskrywing daarvan die betekenisonderskeiding "onbillikheid" ook noem in die definisie "partiality, or bias, in the treatment of a person or group, which is UNFAIR ..." (my uitheffing - WJB). Dit bring mee dat die uitdrukking "billike diskriminasie" eintlik 'n contradictio in terminis is: "'n billike onbillikheidshandeling".

'n Verdere probleem wat verband hou met sodanige uitleef van die 'billikheidskema' het te doen met die feit dat dit gedra word deur die oordeelsadjektief billik. Die term 'oordeelsadjektief' impliseer dat algemene konsensus oor die eienskap wat die betrokke adjektief benoem, nie sonder meer bestaan nie. Wat die begrip BILLIK verder kompliseer, hou verband met die feit dat dit geïntegreer is in bepaalde sosiale modelle. Lakoff en Johnson (1999:296/297) wys byvoorbeeld op die verskillende billikheidsmodelle wat teen die agtergrond van die MORELE-BOEKE-BALANSEER-metafoor verstaan word, naamlik: 'billikheid ten opsigte van gelyke verdeling', 'billikheid met betrekking tot geleenthede'; 'billikheid ten opsigte van prosessuele verdeling'; 'billikheid gegrond op regte'; 'billikheid gegrond op behoeftes'; 'billikheid gegrond op verdienste'; 'billikheid bepaal deur kontraktuele ooreenkoms'; 'billikheid ten opsigte van gelyke aanspreeklikheid'; 'billikheid in ooreenstemming met die graad van verantwoordelikheid, opgeweeg teen die aard van 'n individu se vermoë'; en 'billikheid ten opsigte van die gelyke verdeling van mag'. Hulle merk tereg op dat "(m)any of our moral disagreements arise from conflicts between two or more of these conceptions of fairness" ... en "there is typically no overarching neutral conception of fairness that can resolve the conflict of values". Die Nederlandse gemeenskap ondervang die billikheidsproblematiek met die beginsel van positiewe diskriminasie ("voorkeursbehandeling van gediscrimineerden", volgens Van Dale Groot Woordenboek der Nederlandse Taal). Of dit minder problematies is, is debatteerbaar.

Al die moraliteitsimpliserende begrippe wat deur die inhoud van die begrip TRANSFORMASIE gedra word, kan nie hier bespreek word nie. Vir hierdie bespreking verdien kontensieuse aspekte met betrekking tot Afrikaans se status vermelding. Teen die agtergrond van die mora- 
liteitskema 'billikheid' word die model van regte tans toegepas op die status van Afrikaans as amptelike en onderrigtaal. Daar is al by verskeie geleenthede die opmerking gemaak dat Afrikaans in die pad van transformasie staan (soos ook hier bo genoem) omdat dit leerlinge en studente se reg om in die taal van hulle keuse onderrig te ontvang, skaad. In sodanige kontekste is die behoud van Afrikaans as enkelmedium van onderrig dus by implikasie onbillik en immoreel. Om die morele boeke te balanseer, word daar dus vereis dat Afrikaans se status afgeskaal word. Hier beweeg die 'billikheidskema' gevaarlik na aan die 'vergeldingskema'. Vanuit 'n ander perspektief word dit bejeën as 'n negatiewe handeling ten opsigte van Afrikaans - veral as diegene wat onderrig in Afrikaans ontvang het, en dit so verkies het, uiteindelik onbillik van hierdie reg ontsê word.

Om Afrikaans se "immorele" status te perpetueer, word daar ook dikwels gewag gemaak van Afrikaans se sogenaamde "ongelukkige verlede", terwyl etikette soos verdukkerstaal (en ander pejoratiewe benaminge - per definisie immorele handelinge: die gee van iets met negatiewe waarde) ook talryk is. Die feit dat Afrikaans in 1976 deur die toenmalige regering aan leerlinge opgedwing is as medium van onderrig in bepaalde vakke - en dat dit as een van drie redes aangevoer word vir die Soweto-opstand (vergelyk Muller, 1979) - kan moeilik moreel geregverdig word.

'n Mens sou tereg ook kon vra: Hoe weeg Afrikaans se sogenaamde "ongelukkige verlede" op teen die Afrikaans se ongelukkige hede?

Aangesien hierdie sogenaamde immorele praktyke (in die naam van die abstraksie Afrikaans) uit 'n ryk geskiedenis van taalontwikkeling uitgesonder, uitgehef en lewend gehou word, beteken dit enersyds dat Afrikaans se morele status deurgaans verdedig moet word (morele optrede ter wille van Afrikaans: om die morele boeke te balanseer). In hierdie opsig word moraliteit en immoraliteit teenoor mekaar geweeg met argumente soos die volgende:

- Indien immorele status as 'n fenomenologiese waarheid vir enige taal sou kon geld, hoedanig is die immorele gewig wat aan Afrikaans toegesê word in vergelyking met dié van Europese tale wat kolonialisme in Afrika moes dra?

- Watter morele regverdiging is daar vir die stigmatiserende etikettering van die kode waarin 'n moedertaalspreker se eerste gedagtes gevorm is - die kode waarin hy/sy in die eerste plek kognitief bemagtig is?

Andersyds hou dit in dat Afrikaans stilswyend of luidkeels as "immoreel" aanvaar moet word (om die morele boeke te balanseer) ter vereffening van toegesegde "morele skuld". Indien dit nie gebeur nie, word dit dan as ontduiking van morele skuld geag. Vanuit 'n ander perspektief word dít dan weer as immoreel beskou - op grond van die eerste beginsel wat vroeër na aanleiding van Lakoff en Johnson (1999:298) genoem is met betrekking tot die basis van die betrokke metafoor: immorele optrede deur die gee van iets met 'n negatiewe waarde. Dit spreek vanself dat hier 'n nimmereindigende kettingreaksie kan ontstaan.

Suid-Afrika het vir 'n tyd lank in die gees van versoening gestaan.

Die begrip VERSOENING balanseer die morele boeke op grond van die skematiese ervaring 'morele wisselwerking': die morele boeke word gebalanseer omdat die gee van iets met positiewe waarde in ewewig gebring word met die ontvang van iets met positiewe waarde - en die ontvang van iets met positiewe waarde word in ewewig gebring met die gee van iets met positiewe waarde.

Binne 'n land met elf erkende amptelike tale sou die bevordering van veeltaligheid juis die manifestasie van hierdie skema binne die betrokke metafoor wees. Hierin lê ongelukkig 
ook 'n klomp angels opgesluit, wat nie binne hierdie bestek in besonderhede beredeneer kan word nie.

Suid-Afrika het tot in 'n stadium ver gevorder op die pad van versoening - en die SuidAfrikaanse gemeenskap is dit beny deur bepaalde konflikgeteisterde gemeenskappe wat nog nie tot by die MORELE-BOEKE-BALANSEER-metafoor gekom het nie, veral hulle wat nog nie die boeke kon balanseer ooreenkomstig die skema 'morele wisselwerking' nie. Dit kan onder andere toegeskryf word aan die feit dat 'n geglobaliseerde wêreld baie kulture met hulle eie opvattings van die waarheid naas mekaar en teenoor mekaar te staan gebring het. En bedreigings teen wat as waarheid bejeën word, gee meestal aanleiding tot die ontketening van kragte met 'n sterk moraliteitsbasis - en hoe meer fundamentalisties die waarheidservaring, hoe meer ongenuanseerd is die morele skema wat gepaardgaande optrede onderlê. Daarom is negatiewe gebeurtenisse soos die volgende meestal manifestasies van die 'vergeldingskema' in 'n poging om die morele boeke te laat klop: terreur van 11 September 2001; die oorlog in Irak; terreuraanvalle in Parys, Brussel en elders; en nog baie meer.

Oor wat as waarheid beskou word, sal daar nooit eenstemmigheid wees nie - ook nie in Suid-Afrika nie. En daarom het die oorgang na 'n nuwe bedeling hier te lande meestal ook nie in ooreenstemming met die uitlewing van 'morele wisselwerking' geskied nie. Vir baie is die morele boeke ook nog nie behoorlik gebalanseer nie - veral nie wat Afrikaans se status betref nie. Daarom sal die uitlewing van die 'billikheidskema' met groot omsigtigheid moet geskied, ook wat die ontmagtiging van Afrikaans betref - anders mag dit net wees dat die morele boeke (ook op ander terreine) nooit werklik gaan klop nie.

\section{SLOTWOORD}

Aan die begin van hierdie betoog is daarop gewys dat Afrikaans (soos ander tale) nie slegs 'n kommunikasiemedium is nie. Indien as uitgangspunt geneem word dat Afrikaans slegs kommunikasiemedium is, word die morele implikasies ten opsigte van besluite oor die toekoms van Afrikaans se hoër funksies omseil.

Daar is ook op gewys dat die betekenis van die woord Afrikaans nie eenduidig is nie - en dat ideologies gedrewe simboliese "betekenis" tot die konvensionele betekenisonderskeidings in die verlede toegevoeg is, op die oomblik toegevoeg word en in die toekoms toegevoeg sal word.

Verder is aangetoon hoedat Afrikaans in die spervuur was en is op grond van die metafoorstatus AFRIKAANS IS 'N LEWENDE ENTITEIT - en op grond daarvan is affektiewe konnotasies tot Afrikaans se betekenis toegevoeg. Daarom is Afrikaans om bepaalde redes (ideologies en andersins) negatief verknoop aan die transformerende kragte en magte van 'n veranderende Suid-Afrika.

Besluite oor die status van Afrikaans se hoër funksies wat reeds geneem is, of in die proses is om nog geneem te word, het in die verlede en sal in die toekoms verreikende gevolge vir Afrikaans (as táál en nie noodwendig as simbool nie) inhou. Dit is feitlik vanselfsprekend dat die aard van die besluite ook kritieke implikasies vir die hoërfunksie-ontwikkeling van die ander Afrikatale sal hê. Daarom is en was sodanige besluite vanuit morele oorwegings nie 'n maklike taak nie. Die aard van die kompleksiteit van hierdie dilemma kan weer eens aan die hand van die drama Germanicus geïllustreer word, juis omdat NP van Wyk Louw hom in sy dramas (en ook van sy gedigte) bemoei het met die aard van die daad (veral die daad wat taal is) en die morele implikasies daarvan. In dié drama word die intrinsieke spanning tussen die elemente van moraliteit en immoraliteit tot breekpunt gevoer wanneer dit wat reg is, nie 
noodwendig goed is nie, en wat goed is, nie noodwendig reg is nie. Dit kulmineer in verskillende opvattings van mens-wees teen die agtergrond van diens aan en instandhouding van die Romeinse Ryk - in Piso se woorde uitgedruk as: “... 'liefde', 'vriendskap', 'menslikheid', dít is jul woorde - nooit meer 'eer' en 'plig' ...” (Germanicus, 1961:41).

Teen die agtergrond van die gehele voorgaande bespreking moes/moet daar dus, voordat ingrypende besluite oor Afrikaans se hoëfunksiestatus geneem is/word, eers antwoorde gevind word op onder andere die volgende vrae - ook ten opsigte van verdere ontmagtiging van Afrikaans:

- Is/word die besluit(e) ten opsigte van Afrikaans geneem op grond van wat ons weet reg of verkeerd, goed of sleg is, óf wat ons dínk reg of verkeerd, goed of sleg is, óf wat ons glo reg of verkeerd, goed of sleg is, óf wat ons voel reg of verkeerd, goed of sleg is - óf op grond van emosiebelaaide eise, ondersteun deur taalmetafore, konseptuele metafore, liggaamsmetafore en konfronterende taalhandelinge?

- Is/word besluite geneem op grond van simboolwaardes (meestal op grond van ideologiese eise) wat aan Afrikaans toegedig word - of staan Afrikaans se sentrale betekenis ('n abstraksie wat dui op 'n versameling abstrakte grammatikale, betekenisen ander strukture wat taalgebruikers in staat stel om sinvol betekenis te skep, oor te dra en te verstaan) in die sentrum van besluitneming? In laasgenoemde geval (moes)/ moet daar rekening gehou word met die feit dat Afrikaans oor 'n gesofistikeerde grammatikabeskrywing beskik, 'n rykdom aan idiomatiese uitdrukkings het wat net in Afrikaans werklik seggingskrag het, 'n internasionaal gerespekteerde letterkunde het, oor 'n woordeboekskat beskik wat verskillende terreine van die wetenskap en tegnologie bestryk, oor uitnemende vakliteratuur beskik ... en so kan daar voortgegaan word om die bestaansreg van Afrikaans as hoëfunksietaal te beskryf. Met die afskaling en ontmagtiging van Afrikaans sal (of is daar reeds?) al hierdie wesenselemente (of metafories gestel: hierdie sielselemente) van Afrikaans stagneer en uiteindelik kwyn - nie onmiddellik nie, maar gestadig. Op grond hiervan (moes) behoort hoëronderwysinrigtings hulle dan ook te vergewis (het) van die moontlikheid van 'n paradoksale bestaan: ontsluiting van kennis versus verarming van kennis.

Die belangrikste oorweging wat egter behoort te geld (moes geld), hou verband met die moraliteitskemas op grond waarvan besluite geneem word: morele wisselwerking, of watter skema ook al. Dan moet ook in gedagte gehou word dat moedertaalsprekers van Afrikaans se besluitneming moontlik deur ander moraliteitskemas gerig sal word as wat dit die geval mag wees ten opsigte van niemoedertaalsprekers as besluitnemers.

Of ... speel morele oorwegings nog hoegenaamd 'n rol (in Suid-Afrika)?

\section{BIBLIOGRAFIE}

Accent Software International. 1998. Webster's New World Dictionary \& Thesaurus (Version 2), Macmillan Publishers: elektroniese uitgawe.

Botha, Willem J. 2002. Die Afrikanerprototipe. In Eep Francken \& Ariane van Santen (reds.). Pinguïns en pikkewyne. Leiden, Nederland: SNL, pp. 77- 95.

Botha, Willem J. 2004. The semantics of transformation. 2004. CD-publikasie - Identity and Creativity in Language Education. Proceedings of the 21st World Congress of the World Federation of Modern Language Associations / Fédération Internationale des Professeurs de Langues Vivantes (FIPLV), 2 - 5 July 2003, RAU, Johannesburg, South Africa. ISBN 0-620-31884-8. Publisher: RAU.

Botha, Willem J. 2004. Betekeniservaring en betekenisgesag van die woordeboek. Journal for Language Teaching / Tydskrif vir Taalonderrig, 38(1):130-142. 
Botha, Willem J. 2007. Linguistic mechanisms of power and force: two case studies. 2007. In Larissa Manerko (ed.). Cognitive Linguistics: New Problems of Cognition. Москва (Moskou): Рязань, pр. 14-20.

Botha, Willem J. 2020. Die daad onthul (im)moraliteit. Tydskrif vir Geesteswetenskappe, 60(2):366-379.

Damasio, Antonio. 2006. Descartes' error. Emotion, Reason and the Human Brain. London: Vintage Books.

Dirven, René \& Marjolijn Verspoor (reds.). 1999. Cognitieve Inleiding tot Taal en Taalwetenschap. Leuven: Acco.

Geeraerts, Dirk (red.). 2001. Van Dale Groot Woordenboek der Nederlandse taal (version 1.1 Plus). Utrecht: elektroniese uitgawe.

Giliomee, Hermann. 2004. Die Afrikaners. 'n Biografie. Kaapstad: Tafelberg.

Giliomee, Hermann. 2019. The Rise and Demise of the Afrikaners. Kaapstad: Tafelberg.

Lakoff, George. 1987. Women, Fire and Dangerous Things: What Categories reveal About the Mind. Chicago: University of Chicago Press.

Lakoff, George. 1997. How Unconscious Metaphorical Thought Shapes Dreams. In Dan J. Stein (ed.). Cognitive Science and the Unconscious. Washington: American Psychiatric Press.

Lakoff, George \& Mark Johnson. 1999. Philosophy in the Flesh. The Embodied Mind and Its Challenge to Western Thought. New York: Basic Books.

Lakoff, George. 2004. Don't think of an elephant! Vermont: Chelsea Green Publishing.

Lakoff, George. 2009. The neural theory of metaphor. Elektroniese kopie: http://ssrn.com/ abstract=1437794 (geraadpleeg: 30 Julie 2020).

Langacker, Ronald W. 1967. Language and its Structure. New York: Harcourt.

Leech, Geoffrey. 1974. Semantics. Harmondsworth: Penguin Books Ltd.

Louw, N.P. van Wyk. 1961. Germanicus. Kaapstad, Bloemfontein, Johannesburg: Nasionale Boekhandel.

MacLaury, R.E. 1991. Prototypes revisited. Annual Reviews Anthropology, 20:55-74.

Microsoft. 1999. Encarta World English Dictionary. Seattle: elektroniese uitgawe.

Muller, C.F.J. (red.). 1979. Vyfhonderd jaar Suid-Afrikaanse geskiedenis. Logos Library System: elektroniese uitgawe.

Netwerk24. 2014. https://www.netwerk24.com/Nuus/Dink-nuut-oor-plek-vir-Afrikaans-20140627 (geraadpleeg 28 Augustus 2020).

Netwerk24. 2015. https://www.netwerk24.com/Stemme/Aktueel/Waarheen-met-Afrikaans-20150616 (geraadpleeg 28 Augustus 2020).

Netwerk24. 2015. https://www.netwerk24.com/Stemme/Menings/sonja-loots-wees-eerlik-oor-wat-opdie-spel-is-in-taaldebat-20151128 (geraadpleeg 28 Augustus 2020).

Netwerk24. 2019. https://www.netwerk24.com/Stemme/MyStem/ek-haat-nie-afrikaans-skryf-panyazalesufi-20190607-2 (geraadpleeg 28 Augustus 2020).

Netwerk24. 2020. https://www.netwerk24.com/Nuus/Onderwys/lesufi-vaar-uit-teen-appelhof-uitspraakoor-unisa-taalbeleid-20200721 (geraadpleeg op 3 Augustus 2020).

Oakley, Todd V. 1998. Conceptual blending, narrative discourse, and rhetoric. Cognitive linguistics 9(4):321-360.

Steyn, J.C. 2014. 'Ons gaan 'n taal maak'. Afrikaans sedert die Patriot-jare. Pretoria: Kraal Uitgewers.

Sweetser, Eve. 2003. Levels of meaning in speech and gesture: Real space mapped onto epistemic and speech-interactional mental spaces. Keynote lecture, $8^{\text {th }}$ International cognitive linguistics conference: Cognitive Linguistics, Functionalism, Discourse Studies: Common ground and new directions. University of La Rioja, Spain: Logroño.

Taylor, John R. 1995. Linguistic Categorization. Prototypes in Linguistic Theory. Oxford: Clarendon Press.

Wet 108 van 1996, Republiek van Suid-Afrika. 1996. Die Grondwet van die Republiek van Suid-Afrika. Van der Walt, Hannes \& Hennie Steyn. 2016. Afrikaans as taal van onderrig en leer in skole en ander onderwysinstansies: "Ou" wyn in nuwe sakke. Tydskrif vir Geesteswetenskappe, 56(4-1):1034-1047. 